GEOLOGICAL SURVEY CIRCULAR 699

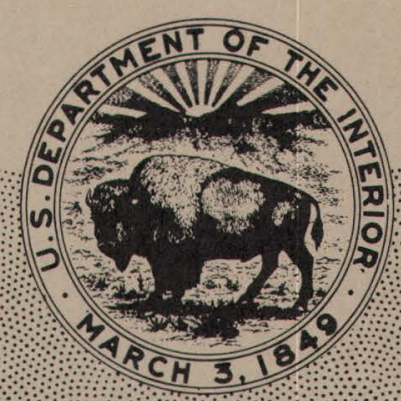

Gold in the Black Hills, South Dakota, and How New Deposits Might Be Found 



\section{CONTENTS}

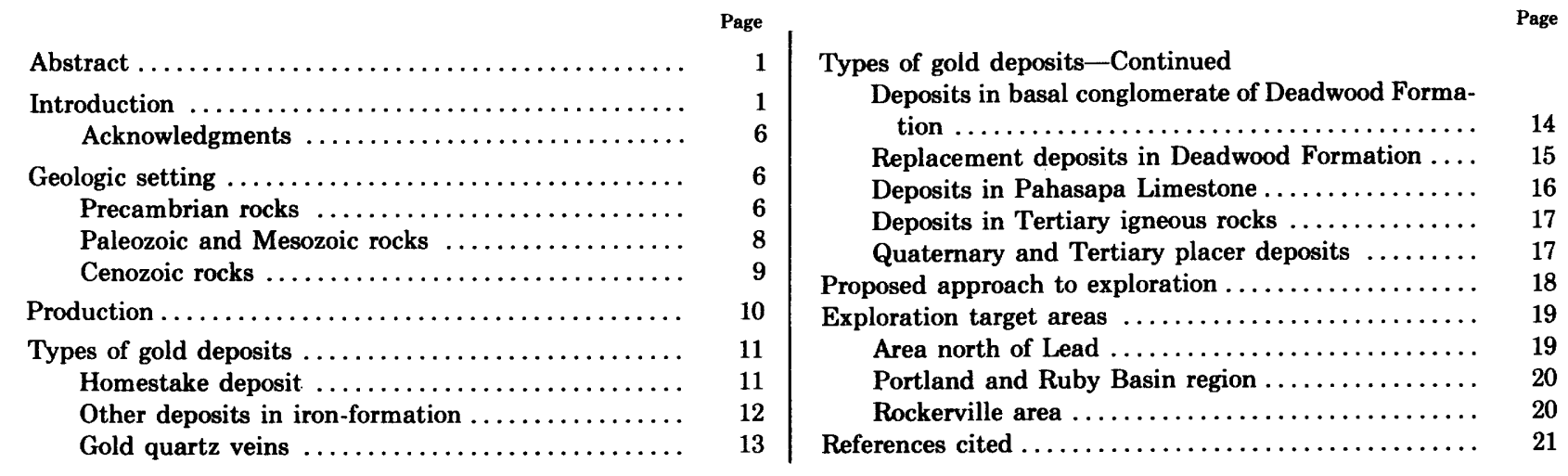

\section{ILLUSTRATION}

FIGURE 1. Generalized geographic and geologic map of the Black Hills of western South Dakota and adjacent parts of Wyoming

Page (n)

\section{TABLE}





\title{
Gold in the Black Hills, South Dakota, and How New Deposits Might Be Found
}

\author{
By James J. Norton
}

\section{ABSTRACT}

Of the recorded production of $34,694,552$ troy ounces of gold mined in South Dakota through 1971, about 90 percent has come from Precambrian ore bodies in the Homestake mine at Lead in the northern Black Hills. Most of the rest has come from ore deposited in the Deadwood Formation (Cambrian) by hydrothermal replacement during early Tertiary igneous activity. About 99 percent of the total production has been within a radius of 5 miles $(8 \mathrm{~km})$ of Lead. Elsewhere, prospecting has been intense, both in the Precambrian rocks, which are exposed over an area 61 by 26 miles ( 98 by $42 \mathrm{~km}$ ), and in nearby Paleozoic rocks.

All the known ore bodies have been found either at the surface or in subsurface workings of operating mines. Efforts to find totally new deposits have been modest and sporadic; no comprehensive and systematic program has ever been attempted.

Obviously, any exploration program should be aimed at finding a new deposit resembling the Homestake in the Precambrian, but discovery in the Deadwood of a new group of ore bodies containing several hundred thousand ounces of gold would certainly be worthwhile.

Evidence has long been available that the Deadwood deposits and the Homestake deposit are somehow related. Current opinion is that (1) the Homestake ore is mainly Precambrian, (2) a trivial amount of Homestake ore is Tertiary, (3) gold in Deadwood basal conglomerate is largely of placer origin, and (4) the gold of replacement deposits in the Deadwood and in other rock units came originally from sources similar to the Homestake deposit or its parent materials.

Homestake ore is virtually entirely contained in a unit of ironformation locally known as the Homestake Formation, which seemingly had more gold in the original sediments than similar rocks exposed elsewhere in the Black Hills. Gold, sulfur, and other constituents were subsequently concentrated in ore shoots in zones of dilation caused by cross folds that deformed earlier major folds. These ore shoots are in metamorphic rocks of a grade just above the garnet isograd, in a zone where the principal iron-magnesium mineral of the iron-formation changes from a carbonate (sideroplesite) to a silicate (cummingtonite). This metamorphic reaction would release carbon dioxide to the fluid that presumably formed the ore bodies.

In short, three controls over localization of the ore have been identified: (1) the cross folds; (2) the so-called Homestake Formation, which passes beneath Paleozoic rocks north of Lead and has not been proved to reappear anywhere else in the Black Hills
(Other units of iron-formation less enriched in gold might locally become more like the Homestake Formation beneath the cover of Paleozoic rocks.); (3) proximity to the garnet isograd-nearly all the exposed Precambrian rocks in the Black Hills are at a metamorphic grade higher than this isograd-and occurrence of this isograd zone mostly beneath Paleozoic rocks.

In searching for new deposits, one can guess from existing data where Precambrian rocks of suitable nature may be concealed. The usefulness of such guesses can be increased if they are made with information about the distribution of gold in younger rocks. Gold in the Deadwood basal conglomerate would be the simplest indicator of a deposit once exposed on the preDeadwood surface. Tertiary replacement deposits in the Deadwood or other rocks, which obtained their gold from Precambrian sources that may be nearby or far away, can also be helpful; they, like anomalies found by geochemical sampling, at least outline the regions of mineralizing activity.

A suitable approach to exploration is to make a thorough study of the stratigraphy, the structure, and the metals geochemistry of the Deadwood Formation and associated rocks, chiefly in the northern Black Hills but to a lesser extent elsewhere in localities where the Precambrian geology seems promising and where gold has been found nearby. Such a program, even if it does not yield a new Precambrian deposit, might lead to the discovery of buried Deadwood deposits of minable grade and size. Areas that, from available information, seem worthy of close attention are (1) north of Lead; (2) the region including the Portland and the Ruby Basin districts, west and southwest of Lead; and (3) the Rockerville area, which is on the east flank of the central part of the Black Hills.

\section{INTRODUCTION}

The Homestake gold deposit, at Lead in the northern Black Hills, S. Dak., is in Precambrian rocks exposed in a Tertiary dome surrounded by Paleozoic sedimentary rocks and Tertiary intrusions. The site of the original outcrop of the deposit has outliers of the Deadwood Formation (Cambrian) in its immediate vicinity, and the edge of the main body of Paleozoic cover is as little as 2 miles $(3.2 \mathrm{~km})$ away. Had erosion never removed 
the Paleozoic blanket from a small but critical area, the Homestake deposit might still be undiscovered. If, in uneroded circumstances, the deposit had in fact been discovered, it would probably have been because a small gold mine in conglomerate at the base of the Deadwood accidentally led miners to the Homestake lode.

With the exception of the Homestake mine and the Bald Mountain mine, which is in the Deadwood Formation 3 miles (almost $5 \mathrm{~km}$ ) west of Lead, all the gold mines in the Black Hills have been closed for more than 30 years, and many have not been worked since the period of intense gold activity near the turn of the century. Few workings are now accessible, and opportunities for detailed geologic mapping and comprehensive modern geologic investigations have not existed for more than a generation.

As the final draft of this paper is being written (Feb. 1974), however, the open-market price of gold is about $\$ 150$ per ounce. Though severe fluctuation has been experienced in recent months, partly as a consequence of speculation, the price of gold seems likely to remain generally high because of demand in industry and the jewelry business and because of the tendency in many parts of the world to fall back on gold at any sign of monetary weakness.

Renewed gold activity in the Black Hills seems inevitable. Old mines will be reopened, though most of them are small and have had little or no success. Allsman (1940) described nearly 100 gold properties, and the Black Hills Mineral Atlas of the U.S. Bureau of Mines (1954, p. 19-22, 95; 1955, p. $24-25,141)$ identified 225 properties. These do not include the countless ephemeral placer operations of the region. Yet, as table 1 shows, very few of the many deposits that have attracted the energy and funds of their supporters have been important. Only one mine - the Homestake - has been large by modern standards; two other groups of properties-the Bald Mountain and (though there is uncertainty in the data) the Golden Reward-have produced nearly 1 million ounces of gold apiece; only four other localities have exceeded the 100,000-ounce level.

Obviously, an effective enlargement of Black Hills gold production can be achieved only by finding deposits at least as large as those of the Bald Mountain or the Golden Reward operations and preferably of a size approaching that of the Homestake deposit. The chief purpose of this paper is to argue that geologic investigation of the Deadwood Formation can direct the way to other Homestake-type deposits if such deposits exist beneath the Paleozoic rocks. Perhaps the Homestake is the only major gold deposit in the Black Hills, but existing evidence, some of it recently obtained but most of it long available and little noticed, indicates that areas of considerable potential have been only slightly investigated or totally neglected.

A resumption, however, of the simple prospecting of the past in rocks at or near the surface is unlikely to result in the discovery of a Homestaketype deposit. Many thousands of prospect pits dot the Black Hills. Most gold pits are in locations that indicate the prospector knew well enough which rocks and perhaps even which structures are most favorable; some pits are in unlikely or even absurd places, such as the quartz cores of pegmatites and ordinary schist with quartz veinlets, whereas others were merely dug in handy locations to meet assessment requirements.

Of course major deposits may have been overlooked because mineralization stopped short of the present surface or because the gold is very fine grained or occurs in such odd minerals that it was not readily detected by the panning and assaying techniques generally used in the past. These possibilities can, and undoubtedly soon will, be tested by diamond drilling at old mines or at places determined to be favorable by the recent work of Bayley $(1970,1972 a, b, c)$. Such work should at the very least bring to light the existence of previously undetected, but probably small, ore shoots.

The obvious alternative is to search beneath and within the Paleozoic rocks. In recent decades the knowledge of the Black Hills Precambrian rocks has vastly increased, especially through (1) the work of Bayley $(1970,1972 a, b, c)$ in the northern Black Hills, (2) the clarification of the origin of the gold deposits through work on stable isotopes by Rye and Rye (1974), (3) the comprehensive review by Shapiro and Gries (1970) of ore deposits in Paleozoic sediments and Tertiary intrusive rocks, (4) the modern improvements in exploration techniques, and (5) the existence now of largescale topographic base maps. All these can facilitate a new and perhaps more effective search for concealed gold deposits.

Figure 1 shows the geography and geology of the Black Hills in a generalized way. For additional information, the maps likely to be most useful and most easily obtained are those of Irving (1904), Darton and Paige (1925), Kleinkopf and Redden (1974), and the Lead topographic quadrangle 
Principal mines:

Homestake .............

Golden Reward group of mines .

Bald Mountain group of mines .

Mogul ..................

Placers of Deadwood region ....

Maitland (Penobscot) ........

Wasp No. 2 .............

Keystone and Holy Terror .....

Gilt Edge ...............

Spearfish Gold ............

Clover Leaf (or Uncle Sam) ....

Lundberg, Dorr, and Wilson ....

Hoodoo-Union Hill . . . . . . . . .

Reliance ................

Rockerville placers .........

Ragged Top

Deadwood Standard

J.R. ....................

Hidden Fortune . . . . . . . . . .

Other deposits: ${ }^{11}$

Lawrence County (especially Alder Creek, Cleopatra, Bismarck, Golden Crest, Monarch, and Kicking Horse). ${ }^{12}$

Pennington County (especially Empire, Bullion, Standby, and Sunnyside). ${ }^{12}$

Custer County ...........
At Lead, Lawrence County .....

$2 \mathrm{mi}$. $(3 \mathrm{~km}) \mathrm{SW}$. of Lead ....

$3 \mathrm{mi}$. $(5 \mathrm{~km}) \mathrm{W}$. of Lead .......

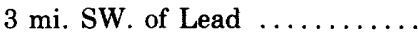

Near Deadwood ..............

$3 \mathrm{mi}$. NNW. of Lead ..........

$2 \mathrm{mi}$. S. of Lead .............

At Keystone, Pennington County

$5 \mathrm{mi} .(8 \mathrm{~km}) \mathrm{ESE}$. of Lead .....

$7 \mathrm{mi} .(11 \mathrm{~km}) \mathrm{W}$. of Lead .....

At Roubaix, $7 \mathrm{mi}$. SE. of Lead .

$2 \mathrm{mi}$. WSW. of Lead .........

$5 \mathrm{mi}$. ESE. of Lead ..........

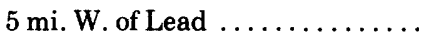

Just E. of Rockerville, Pennington County ...........

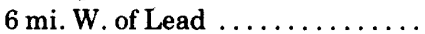

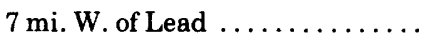

$3 \mathrm{mi}$. N. $60^{\circ}$ E. of Hill City, Pennington County ...........

Just N. of Lead ............

$€ \mathrm{dd}$

10,997

€dd

50,000

Total production from identified sources

$34,536,246$

Production from unidentified sources 158,306

Total recorded production

$34,694,552$

${ }^{1}$ p if, Precambrian iron-formation; $p € q$, quartz veins in Precambrian metamorphic rocks; $€ \mathrm{dc}$, conglomerate at the base of the Deadwood Formation; $€$ dd, replacement bodies and veins in dolomite and other rocks of the Deadwood Formation; Mp Pahasapa Limestone; Ti, Tertiary igneous rocks; QTp, Quaternary and Tertiary placer deposits.

${ }^{2}$ Chief source of information is Allsman (1940); other sources (except for the Deadwood and Rockerville placers) are U.S. Bureau of Mines Minerals Yearbooks Reports of the South Dakota State Mine Inspector, Slaughter (1968, p. 1438), U.S Bureau of Mines $(1954,1955)$, Irving (1904, p. 117-118), and Shapiro and Gries (1970, p. 190-194). Many figures are in part estimates, several of which are based on published statements of the probable dollar value of production during years prior to published statements of the probable dollar value of production during years prior to tained by subtracting the published or probable production figures of other mines from the total South Dakota production in that year. from the total South Dakota production in that year. as only 371,382 ounces of gold and 734,223 ounces of silver, but he stated that in complete records for earlier years suggest a total production of about $\$ 21$ million in bullion. This large total implies that the Golden Reward gold production cannot have been less than the 950,000 ounces used here, which makes the Golden Reward group of properties the second largest source of gold in the Black Hills. The Bald Mountain group of mines has traditionally been regarded as holding the second ranking position, and tradition may well be correct, for its production of 836,000 ounces is almost completely documented.

The production of the Bald Mountain group of mines is the total of (1) 487,877 ounces for 1901-37 published by Allsman (1940, p. 28); (2) about 342,000 ounces for 1938-59 either known or readily deduced as coming from the Bald Mountain operation from U.S. Bureau of Mines Minerals Yearbook figures and from Slaughter (1968, table 1); and (3) apparently small production prior to 1901, of which only an es timated 5,700 ounces from the Clinton and Dividend properties seems to be recorded (Irving, 1904 p. 118) This brings the total, in round figures, to 836,000 ounces. Unfortunately Miller (1962 p. 114-115), whose data should bes, to 836,000 ounces. Unforthat (after subtracting the Mogul production, which is here treated separately) total only 757,858 ounces. Miller and Allsman are substantially in agreement for the period 1901-37. The main discrepancy lies in the 1938-59 figures, for which Miller seems to use 271,561 ounces instead of the 342,000 ounces used here.

${ }^{5}$ Allsman (1940, p. 38) recorded production of 212,679 ounces for 1902-17. He also said that scattered records indicate about $\$ 3$ million in bullion produced in earlier years. This amount, after allowance is made for silver, suggests 138,000 ounces of gold, which brings the total gold production, in round figures, to 350,000 ounces. ${ }^{6}$ Bergendahl (1964, p. 44). Source of information is unstated, but oral communications with him and A.H. Koschmann during the late 1950 's, when they were compiling gold production data from many sources, suggest that this figure is based on U.S. Mint records of gold receipts from this region during years when the only large production was from placers at Deadwood.

${ }^{7}$ Allsman $(1940$, p. 40) recorded 100,819 ounces for $1901-20$ and said that $\$ 500,000$ or less was produced in earlier years, which indicates a total of about 120,000 ounces. less was produced in earlier years, which indicates a total of about 120,000 ounces.
${ }^{\circ}$ Omits Allsman's figure of 3,150 ounces for 1899 , which according to Shapiro and 8 Omits Alsman's figure of 3,150 ounces for 1899 , which accor
Gries (1970, p. 167) came mostly or entirely from elsewhere.

Gries (1970, p. 167) came mostly or entirely from elsewhere.
9The Hoodoo-Union Hill deposits (Allsman, 1940, p. 63) had a production of at The Hoodoo-Union Hill deposits (Allsman, 1940, p. 63) had a production of at
least $\$ 150,000$ in gold, and the company owning the property produced $\$ 800,000$ from least $\$ 150,000$ in gold, and the company owning the property produced $\$ 800,000$ from
this and other sources. The 30,000 -ounce estimate used here is nearer the larger figure this and other sources.
than the smaller one.

${ }^{10}$ Parker (1966, p. 87) seems to be the only author who has ventured an estimate of
than the Rockerville production, which, without citing a source, he places at $\$ 400,000$ in 1877 and 1878 and at more than $\$ 500,000$ within a few years thereafter. The amount of disturbed ground in Rockerville Gulch and along the base of the Deadwood Formation suggests that production was indeed substantial, but it was probably not as large as Parker states. The estimate of 20,000 ounces used here is merely a guess but probably is as accurate as any that can be made now.

"None of the hundreds of small placer deposits mined after the gold rush years are included.

${ }_{12}^{12}$ Mines specifically named are those that have a recorded or estimated production of between 3,000 and 10,000 ounces. 


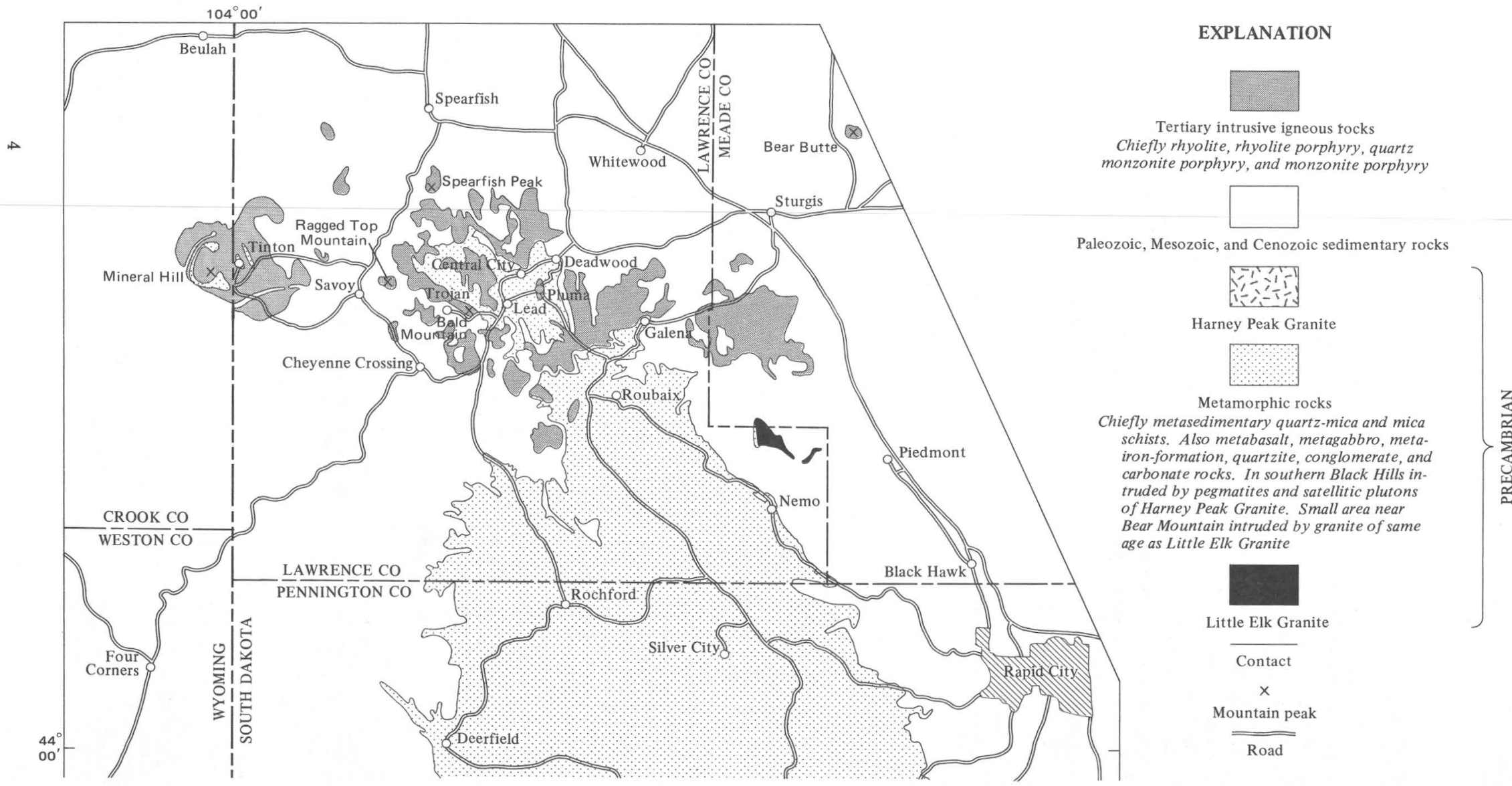




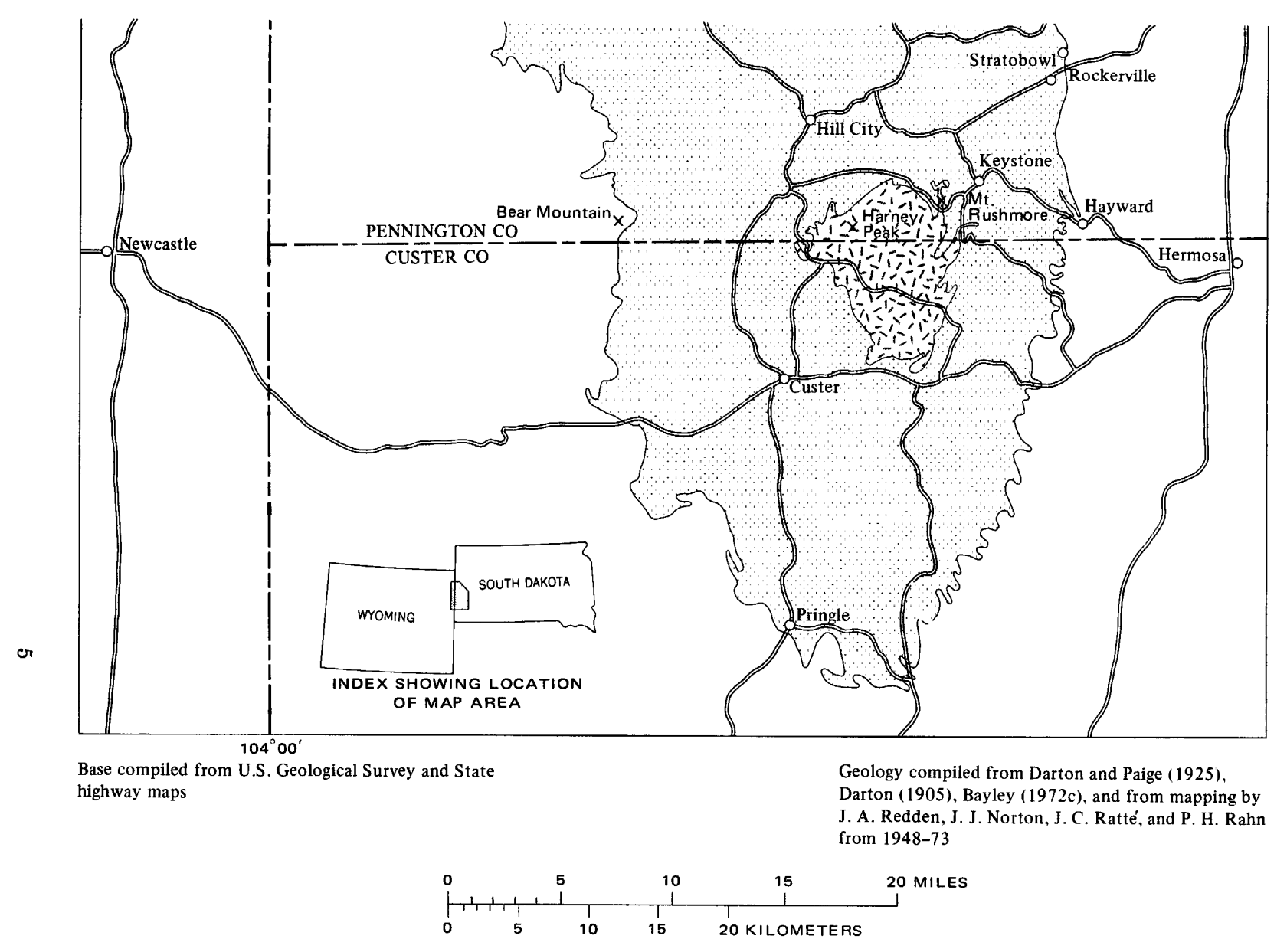

Figure 1.-Generalized geographic and geologic map of the Black Hills of western South Dakota and adjacent parts of Wyoming. 
(scale 1:24,000) and adjacent quadrangles. The literature cited in the list of references is replete with other maps and information for the serious reader. Because, however, the body of published literature and unpublished but obtainable reports on the Black Hills is lengthy and often tends to obscure rather than clarify the merits and suitable methods of exploring for gold, another purpose of this paper is to summarize what appears to be the critical information and to refer the reader interested in exploration to other reports from which he can form his own opinions.

\section{ACKNOWLEDGMENTS}

Perry Rahn, South Dakota School of Mines and Technology, graciously showed me in 1972 the Deadwood conglomerate and the Quaternary placer deposits at Rockerville, which I had previously suspected were far smaller than indicated by published accounts in newspapers and in books written for popular consumption.

\section{GEOLOGIC SETTING}

The Black Hills is a dome consisting of a Precambrian core flanked by Paleozoic and younger sediments. Tertiary rhyolitic, monzonitic, and alkalic intrusions are abundant in the northern Black Hills but are absent in the south. Literature on all aspects of the geology runs to so many thousands of pages that only highlights pertinent to the questions at hand can be mentioned here.

\section{PRECAMBRIAN ROCKS}

The area of exposed Precambrian rocks is oval in shape, elongate in a north-northwesterly direction, and 61 miles $(98 \mathrm{~km})$ long and as much as 26 miles $(42 \mathrm{~km})$ wide. Small bodies of granite in two separate localities have been dated at about 2.5 billion years (Zartman and Stern, 1967; Ratté and Zartman, 1970). One of these is the Little Elk Granite north of Nemo, which unconformably underlies the small quantity of adjacent Precambrian rocks and is otherwise completely surrounded by the Deadwood Formation. The other is near Bear Mountain, in the west-central part of figure 1; there, the granite has intruded metasedimentary micaceous schist, thus indicating that sedimentation in this region was exceedingly ancient. Another granite, the Harney Peak Granite, which with its many pegmatites is a prominent feature of the southern Black Hills, is $1,744 \pm 12$ million years old (Riley, 1970, p. 716-718). Metagabbro, which is modestly abundant, is the only other kind of intrusive rock. The Harney Peak Granite is the youngest Precambrain rock known in the area, though the Sioux Quartzite, of much later age, extends in the subsurface to a point about 100 miles east of the Black Hills (Steece, 1964, p. 28-31).

Approximately three-fourths of the Precambrian rocks consist of schist or phyllite derived from shale, graywacke, and subgraywacke. Metabasalt, not uncommonly having pillow structure, is abundant at several localities from the Lead region to the south border of Pennington County. The best examples are on maps by Bayley $(1970,1972 a, b$, c), who was in fact the first to recognize the metabasalt for what it is; previous authors had argued about whether it was metamorphosed carbonate sediment or plutonic rock (for example, Berg, 1946, p. 30-41). Other metamorphic rocks include cummingtonite-grunerite iron-formation, cherty and clastic quartzites, conglomerate, and carbonate rocks. The units of iron-formation, though they occur at several stratigraphic levels, are insignificant in quantity but are the most prominent host for gold.

Metamorphism ranges from moderate to rather high intensity. The Lead region, according to Noble and Harder (1948, pl. 1), has a biotite zone in the west, then a garnet zone, and finally a small area in the northeast containing staurolite and extending beneath the Paleozoic cover. Further south, in areas mapped by Bayley $(1970,1972 \mathrm{a}, \mathrm{b}$, c), most localities have at least some garnet, though small parts of the region may be in the biotite zone. Still further south, on the north flank of the Harney Peak Granite dome, both staurolite and sillimanite isograds appear. From there to the southern border of the Precambrian exposures, all metamorphic rocks are in the sillimanite zone.

The rocks have undergone several periods of deformation. Tight or isoclinal folds of north to north-northwest trend predominate. Refolding has been recognized in many places. Dips of bedding and schistosity generally exceed $60^{\circ}$, either east or west, except on the flanks of granite domes. Even the volcanic piles of metabasalt, though of approximately oval form in many places on a geologic map, are surrounded by very steep dips.

Faults are abundant. Some are very ancient, for they were healed and deformed during the metamorphic and tectonic events accompanying intrusion of the Harney Peak Granite. Other faults are young enough to displace Tertiary intrusions (Irving, 1904, pl. 9). A few faults that are wholly within Precambrian rocks contain breccia of very 
fresh appearance and even slickensides (for example, in the Bullion mine at Keystone) and thus seem to be very youthful.

Two faults require particular attention. One of them is the Grand Junction fault in the southwest part of the Precambrian area; it was first recognized in the Berne quadrangle northwest of Custer (Redden, 1968, p. 391) and extends from Pringle to Custer and then northwest past Bear Mountain toward Deerfield. Neither during the Berne work nor during subsequent mapping of nearby areas could a persuasive correlation be made between the rocks on the two sides of this fault, except that the oldest rocks on either side belong to the same unit, the Vanderlehr Formation described by Redden (1968, p. 347-354). Presumably the fault has great horizontal displacement, but the stratigraphic discrepancies between the two sides can only be explained by causes that remain undetermined.

The other major fault, mapped by Bayley $(1972 b, c)$, appears from beneath the Paleozoic contact southeast of Galena and strikes generally south to a point west of Nemo and then southeast toward Rockerville. Though Bayley correlates some of the younger rocks east of the fault with rocks to the west, the geologic terranes on the two sides appear quite different. Very old and greatly deformed metasedimentary rocks, which overlie the Little Elk Granite east of the fault are unrepresented elsewhere in the Black Hills, though they show some lithologic similarities but little resemblance in stratigraphic sequence to old rocks west of the Grand Junction fault near Bear Mountain. Metagabbro is more abundant in the Nemo area east of the fault than anywhere else in the Black Hills, and the younger rocks, possibly correlative with the stratigraphic section at Lead, have fewer folds than similar rocks west of the fault (Bayley, 1972b, c).

Most of the area occupied by exposed Precambrian rocks in the Black Hills lies between these two faults. At the northern extremity the stratigraphic section as presented by Noble and Harder (1948, p. 943-952) consists of (1) the Poorman Formation, containing phyllite generally carrying ankerite, which is the oldest formation of the area and generally is farthest north; (2) the socalled Homestake Formation, a 200- to 300-foot (60- to 90-m)-thick unit of iron-formation containing sideroplesite (magnesium-rich siderite) where metamorphism is of low intensity and cum- mingtonite where metamorphism exceeds the garnet isograd; (3) the Ellison Formation, containing phyllite, schist, and dark quartzite; (4) the Northwestern Formation, which resembles the Ellison except for a lack of quartzite; (5) the Flag Rock Formation, of heterogeneous nature, containing phyllite and schist (including pyritic graphite schist) and beds of cherty quartzite and iron-formation; and (6) the Grizzly Formation, a uniform sericitic phyllite.

Further south, in the Rochford area, Bayley (1972a, p. 3, 8, pl. 1) found the structure dominated by an anticlinorium having the Ellison, which he called the Moonshine Gulch Quartzite, at its core and a very great thickness of the Grizzly, which he called the Swede Gulch Formation, on its flanks. In this area, metabasalt and meta-iron-formation are very prominent in the Flag Rock, which Bayley raised to group status.

The Swede Gulch Formation of Bayley is lithologically the same as the unit to the south that Ratté and Wayland $(1969$, p. 2-5) called the Oreville Formation. The total thickness of the Grizzly-Swede Gulch-Oreville rocks amounts to tens of thousands of feet. The Oreville Formation is succeeded by quartz-mica and mica schists which extend to the east and southeast into areas mapped by myself. These rocks have within them four separate stratigraphic units that, like the Flag Rock, contain mica schist interspersed with bodies of iron-formation, cherty quartzite, graphitic schist, and probable metabasalt. Three of these units also have clastic quartzite, and the lowermost unit has bodies of conglomerate containing quartzite fragments in a schist matrix. At two localities the unit containing conglomerate extends into the area mapped by Bayley (1972c); at once place he tentatively called it Flag Rock, and at the other he considered it a phase of the Grizzly Formation. The abundance of folds and faults in the region leaves ample room for argument about these correlations, and indeed about all the stratigraphy summarized in preceding paragraphs; but the pattern of Bayley's map (1972c) implies that he too might have considered placing these units among his youngest rocks.

The stratigraphic section culminates southeast of the Harney Peak Granite in a large area of sillimanite schist containing beds of clastic quartzite. This extends all the way to the south end of the exposed part of the Precambrian core of the Black Hills. 


\section{PALEOZOIC AND MESOZOIC ROCKS}

The Precambrian rocks are surrounded by a stratified sequence of Paleozoic and Mesozoic sedimentary rocks which dip away from the Precambrian rocks. East of the Precambrian exposure the dip is generally moderate but in some places forms a decidedly steep monocline. Dips are very gentle west of the Precambrian exposure, but farther west, in Wyoming, the rocks turn downward in a very steep and large monocline. The overall configuration of the Precambrian-Cambrian contact is shown by a structure contour map compiled by Noble and others (1949, pl. 4).

The oldest Paleozoic unit, and the only one in which ore deposits are abundant, is the Deadwood Formation, which is generally called Upper Cambrian but has Lower Ordovician beds near its top in the northern Black Hills. The stratigraphy and biostratigraphy have been treated in exhaustive detäil in an unpublished thesis by Kulik (1965); a recent published account is by Lochman-Balk (1972). Additional information bearing more directly on the relations between the stratigraphy and the ore deposits can be found in the report by Shapiro and Gries (1970) and in many older references.

The Deadwood Formation consists mainly of sandstone and shale, not infrequently containing glauconite and being interspersed with many beds of intraformational conglomerate. It also has a basal conglomerate and calcic to dolomitic carbonate beds, which are the principal hosts for ore. Ordinarily the basal conglomerate is a pebble bed only a few inches or a few feet thick, but adjacent to topographic highs on the Precambrian-Cambrian contact it can be several tens of feet thick and contain boulders from nearby sources. Otherwise the lower part of the Deadwood consists of sandstone or quartzite with occasional lenses of conglomerate. The thickness can be as much as 60 feet $(18 \mathrm{~m})$ but is generally less than 30 feet $(9 \mathrm{~m})$. Above this are interlayered sandstone, shale, limestone or dolomite, and intraformational conglomerate. These occur in a stratigraphically intricate arrangement described and diagramed by Kulik (1965, especially pls. 2-4). The topmost unit in the formation is the $S$ colithus sandstone facies, named for its abundance of Scolithus borings; this unit exists only in the northern Black Hills.

The thickness of the Deadwood Formation is greatest in the northern Black Hills and diminishes to nothing not far south and southeast of the southernmost Precambrian outcrops (Kulik, 1965, pl. 5; and Lochman-Balk, 1972, fig. 4). The thickest measured section, west of Lead near Ragged Top Mountain, is 462 feet $(141 \mathrm{~m})$ according to Shapiro and Gries $(1970$, p. 219); to the southeast near Rockerville the thickness is about 200 feet $(60 \mathrm{~m}) ; 30$ miles $(48 \mathrm{~km})$ further south the formation lenses out (Kulik, 1965, pl. 5). The most complete exposure is just north of Deadwood in the type section, where the thickness measured by Kulik (1965, p. 239-240) is 411 feet $(125 \mathrm{~m})$.

The change in thickness probably results less from erosion than from nondeposition in the south during north-northwestward regression of the Deadwood sea (Kulik, 1965, p. 13, 165). The details of the stratigraphy indicate a series of transgressions and regressions in which sandstones are the nearshore facies followed by shales and then by occasional offshore limestones (Kulik, 1965, especially p. 14, 149-151, 204). As a result, limestone and dolomite are most abundant in the north and west, and the sandstones and shales to the south and southeast are only rarely interspersed with carbonate rocks.

The environment of deposition was one of shallow seas, lagoons, and tidal flats (Kulik, 1965, especially pls. 14-16). At the onset of sedimentation, however, as the Deadwood sea first advanced eastward from Wyoming, there were many islands, headlands, and embayments caused by irregularities on the Precambrian surface (Kulik, 1965, p. 138-139, pls. 14-15). Most such topographic prominences were formed of quartzite, granite, or amphibolite, but the first island to be identified as such in the literature was formed of the Homestake lode (Devereux, 1882, p. 473). Generally, however, the relief was moderate, probably rarely exceeding 100 feet $(30 \mathrm{~m})$. Nearly lateritic conditions on the pre-Deadwood surface are implied by the very common alteration of amphibole in iron-formation to iron oxide, by other signs of deep weathering at the contact (Redden, 1963, p. 246), and by red stain in basal Deadwood rocks.

Three strata in the Deadwood Formation have been of particular importance to mining. One is the basal conglomerate, especially near Lead, where according to Slaughter $(1968$, p. 1442) its thickness ranges from a few inches to 50 feet $(15 \mathrm{~m})$ but is generally less than 10 feet $(3 \mathrm{~m})$. The other two strata are dolomitic units-one is just above the basal quartzite and conglomerate and the other is 20 to 30 feet $(6$ to $9 \mathrm{~m}$ ) beneath the Scolithus sandstone (Miller, 1962, p. 11-15). Most of the 
Black Hills gold produced from sources other than the Homestake mine is from replacement deposits in these dolomites. Unfortunately the lower of the two dolomite units in the principal gold mining area, west and southwest of Lead, does not appear in the stratigraphic sections measured by Kulik (1965), presumably because surface exposures are inadequate and mine workings were not sufficiently accessible. Only a few logs of drill holes and shafts obtained from various sources by Shapiro and Gries (1970, p. 215-222, 231-232) are helpful in reducing this shortcoming.

The Deadwood Formation is succeeded by three thin units having an overall thickness of about 30 to 200 feet $(9$ to $60 \mathrm{~m}$ ). These are the Winnipeg Formation, consisting of shale and siltstone; the Whitewood Limestone, consisting of dolomite and limestone; and the Englewood Formation, consisting mostly of limestone. The Winnipeg and the Whitewood, both of which are Ordovician, appear only in the northern Black Hills, whereas the Englewood, which is Late Devonian and Early Mississippian, completely surrounds the uplift.

The next major unit is Pahasapa Limestone (Mississippian), equivalent to part of the Madison Group, which under this and other names is widely known in the Rocky Mountains. Its thickness ranges from about 200 to 600 feet (60 to $180 \mathrm{~m}$ ), but the change is not regular-erosion along its upper contact and collapsed solution structures cause great local variations.

The next unit is the Minnelusa Sandstone (Pennsylvanian and Permian), generally about 400 to 500 feet $(120$ to $150 \mathrm{~m})$ thick. Overlying units contain limestone and red beds; the Permian and Triassic red beds form the "racetrack" valley circling the Black Hills, and the Jurassic and Cretaceous units form the outlying hogback region.

Any now-foreseeable exploration drilling for concealed gold deposits would start in units no higher than the Minnelusa, which extends a sizable distance outward from the Precambrian exposures. The thickness to the Precambrian in some localities could be about 2,000 feet $(600 \mathrm{~m})$, especially where there are large Tertiary sills, but more commonly holes could be placed on the Pahasapa or Deadwood Formations so as to require less than 1,000 feet $(300 \mathrm{~m})$ of drilling to reach the base of the Deadwood.

\section{CENOZOIC ROCKS}

The northern Black Hills has an abundance of lower Tertiary intrusive igneous rocks in bodies of many sizes and shapes. A few very small exposures of extrusive rhyolite and obsidian have also been discovered (Darton and Paige, 1925, p. 17).

The intrusive rocks are mainly rhyolite, rhyolite porphyry, quartz monzonite porphyry, and monzonite porphyry. Other rocks include grorudite, which is allied to the rhyolite porphyry except for its abundance of albite and the sodic pyroxene acmite (aegerite), and phonolite (or tinguaite of some reports), which consists of orthoclase and albite together with acmite, nepheline, and a few more rare sodic minerals (Paige, in Darton and Paige, 1925 , p. 16). Phonolites containing quartz are gradational into grorudite. The Tinton area also contains syenite porphyry, nepheline syenite, and pseudoleucite porphyry (Darton, 1905, geologic map).

These rocks form many dikes, sills, stocks, ani probably laccoliths. The term "laccolith," which was much more popular a half century ago than today, was applied by Darton $(1905$, p. 10) and by Darton and Paige (1925, p. 20-23), as well as by other authors, to many of the larger bodies intruding Paleozoic rocks. Noble, Harder, and Slaughter (1949, p. 338-340) doubted this usage, chiefly because the large intrusions exposed in Precambrian surroundings are unquestionably stocks. Their structure contour map of the Precambrian surface (Noble and others, 1949, pl. 4) encouraged this doubt by showing domes and other irregularities in much the same way as on a structure contour map at the top of the Minnekahta Limestone (Permian) (Darton, 1905, fig. $3^{1}$ ); however, the assumptions that Noble, Harder, and Slaughter used in making their map seem to have contributed to their conclusions. Recent work by Anna (1973) on part of the flank of the large instrusion east of Galena indicates the intrusion is indeed a laccolith.

The only modern studies of the petrology and structure of the Tertiary igneous rocks have been in three small areas. One study was by Noble (1948) in the immediate vicinity of the Homestake mine, another was by Mukherjee (1968, p. 48-92, 132-159, 169-209) in the Galena-Gilt Edge mine area, and the most recent was that by Anna (1973) in the area east of Galena. A comprehensive investigation was started in the late 1950's by H. D. Carlson, then of

\footnotetext{
'The bar scale on Darton's figure is in error. The actual scale is 1 inch to about 10.7 miles instead of 1 inch to about 6.5 miles. A similar map published as figure 6 in Darton and Paige (1925) has a corresponding error; its scale is 1 inch to 27 miles instead of 16 miles.
} 
the University of South Dakota, but apparently was not completed.

All other Cenozoic rocks are stream sediments, which are unconsolidated except in a few places where gravel is cemented by iron oxide. The oldest deposits belong to the White River Group (Oligocene), which consists of gravel, sand, clay, and scattered volcanic ash presumably windblown from somewhere to the west or south. These are especially widespread on the southeast flank of the Black Hills on uplands between stream valleys (Darton and Paige, 1925, geologic map). Even within the Black Hills, except at high altitudes, there are scattered outliers of these deposits, some of which are assigned only doubtfully to the White River because they may be younger terrace gravels or may be reworked White River deposits (Darton and Paige, 1925, p. 14).

Modern streams flow generally eastward across Precambrian and then younger rocks. Major exceptions are in the north, where Spearfish and Whitewood Creeks flow north, and in the southwest, where Pleasant Valley Creek flows south. Early Pleistocene drainage seems to have been similar (Earton and Paige, 1925, p. 25). Alluvium of the generally narrow valley bottoms is probably all of Holocene age. Terrace gravels on valley walls and still higher gravels, not necessarily related to the modern drainage system, are of Pleistocene or late Tertiary age. These bodies of gravel, many of which contain placer gold, are rarely more than a few hundred feet long. East of the Black Hills, however, many tens of square miles of such gravel were mapped by Darton and Paige (1925).

\section{PRODUCTION}

Through 1971, the known production of gold amounted to $34,694,552$ troy ounces. Table 1 gives information, chiefly attributable to Allsman (1940), as to where most of the Black Hills gold has been obtained. More than 90 percent of the gold came from the Homestake mine, and about 99 percent came from within a radius of 5 miles $(8 \mathrm{~km})$ of Lead. The Deadwood Formation has accounted for most of the non-Homestake production; placer deposits are probably the third largest producer. Precambrian iron-formations other than those at Homestake have been a very modest source, and 'only a few of the many quartz vein deposits in Precambrian rocks have been important. Deposits in Tertiary igneous rocks and in the Pahasapa Limestone are approximately tied for last place.
Total silver production through 1971 , was 12 ,867,547 troy ounces, of which $7,280,485$ ounces, or 57 percent, came from the Homestake mine (U.S. Bur. Mines Minerals Yearbooks; Slaughter, 1968, p. 1438). The ratio of silver to gold, by weight, in the Homestake mine is 1:4.3 (Slaughter, 1968, p. 1438), yet the ratio in Deadwood deposits is about 1:0.6 (Allsman, 1940, p. 26).

Table 1 is unique in that, unlike previous compilations, it reconciles the sum of the production from individual sources and the total amount of gold known to have come from the Black Hills. Other compilers have directed their attention mainly to the figures available since 1900 because these are generally accurate; most of these figures were first accumulated in a single publication by Allsman (1940). Estimates of production in prior years, many of which also are in Allsman's bulletin, have tended to be overlooked. As a result, about 1 million ounces of gold often go unmentioned. In table 1 most of this missing gold is assigned to the Golden Reward, Mogul, and Bald Mountain operations. The reader who is surprised by differences between table 1 and widely quoted production records will find the major discrepancies explained in footnotes appended to the table.

About 160,000 ounces of gold remain unassignable to a known source; to that figure could probably be added a small amount of gold that was never entered in any records as coming from the Black Hills. Some of the unassigned production came from placer operations in the central and southern parts of the Black Hills, but the total output from these seems to have been very modest. Other gold may have come from Homestake properties before their purchase and thus escaped entry into Homestake records, but this too seems an unlikely cause of major discrepancies. Possibly a few tens of thousands of ounces of unrecorded gold came from Precambrian deposits of small to medium size, for the known history of many of these deposits is plainly incomplete. Undoubtedly, most of the gold for which a source cannot be determined came from mines in the Deadwood Formation, especially from the larger deposits that later came under Bald Mountain or Golden Reward ownership.

The production data show clearly enough that a prospector who subscribes to the adage that one should hunt for elephants in elephant country should direct his most intense efforts to localities within a few miles of Lead. His prime objective 
should be to find a new deposit like the Homestake; however, discovery of a idew area of deposits like those mined in the Deadwood Formation could also be worthwhile.

\section{TYPES OF GOLD DEPOSITS}

\section{HOMESTAKE DEPOSIT}

The ore shoots forming the Homestake deposit are, with a few minor exceptions, confined to the Homestake Formation, as used by Noble (1950, p. $224)$. Though the literature ordinarily neglects to say so except by implication, this is a metamorphosed iron-formation. Its dominant rock is cummingtonite schist, which is interspersed with a modest quantity of cherty quartz. The optical properties of the cummingtonite (Wayland, 1936, table 1) commonly place it near or beyond the boundary with grunerite, and the mineral has in fact been called grunerite in most of the recent publications on other areas in the Black Hills. Cummingtonite is absent in rocks below (west of) the garnet isograd, where sideroplesite (magnesium-rich siderite) is the dominant mineral. The change from sideroplesite to cummingtonite begins almost exactly at the garnet isograd and is completed within a few hundred feet east of it (Noble and Harder, 1948, p. 963-964); the Homestake mine is in the zone of this change.

The ore bodies themselves are groups of pipelike southeasterly plunging shoots, some of which coalesce with other shoots. They are localized in zones of cross folds superimposed on the large regional isoclinal folds (Noble, 1950 , p. 225-230; Slaughter, 1968, p. 1450-1453). Dilation of the rocks, which opened channels for movement of fluid and for ore deposition, is the supposed reason for concentration of ore in these zones. Ore forms only a very small, but unestimated, percentage of the total amount of Homestake Formation known to exist in the northern Black Hills, though geologists unfamiliar with the region have occasionally supposed otherwise.

The ore bodies consist chiefly of chlorite and veins and masses of quartz; 7 to 8 percent is of the sulfides, pyrrhotite, pyrite, and arsenopyrite (Noble, 1950, p. 231; Slaughter, 1968, p. 14551456). The chlorite and quartz can extend hundreds of feet into the adjacent Poorman Formation; pyrrhotite can also extend far into the Poorman, but the gold and the arsenopyrite with which it is commonly associated are generally confined to the Homestake Formation. Noble (1950, p. 231-237) divided the Homestake mineralization into four stages represented by four different mineral assemblages in which, from oldest to youngest, the principal minerals are (1) quartz, chlorite, and arsenopyrite; (2) quartz (continuing from the first stage), ankerite, and pyrrhotite; (3) pyrrhotite (continuing from the second stage); and (4) pyrite and calcite. The first three mineral assemblages were formed prior to the Tertiary rhyolite dikes, and according to R. O. Rye (written commun., 1974), further study has shown that these assemblages can occur in any sequence. Veinlets of pyrite and calcite cut not only the other three assemblages but also the rhyolite. Detectable gold occurs in all four assemblages, though it is sparse in veins of massive pyrrhotite and in the pyrite-calcite assemblage (Slaughter, 1968, p. 1457), and gold is also in nearby unaltered or slightly altered cummingtonite schist. Production statistics from Slaughter (1968, p. 1438) show that from 1946 through 1965 the mine yielded 0.345 ounces of gold and 0.070 ounces of silver per ton of ore.

The age of Homestake gold mineralization has long been disputed; vigorous arguments have been set forth in support of both Precambrian and Tertiary ages. The supposedly detrital (Precambrian, Homestake-derived) gold at the base of the Deadwood and the apparently deep-seated nature of the Homestake mineralization indicate a Precambrian age. The existence of a small percentage of Homestake ore cutting Tertiary igneous rocks and the nearness of the Homestake to the main Deadwood deposits suggest a Tertiary age. Actually the question was never of a clearcut yesor-no kind; the widespread, though sparse, gold in many units of Black Hills iron-formations can be plausibly interpreted only as Precambrian, and the ore cutting Tertiary igneous rocks is obviously youthful. Thus the real question was whether the Homestake ore is mainly Precambrian or mainly Tertiary.

The problem seems now to have been settled by Rye and Rye (1974) through work on stable isotopes, especially of sulfur and oxygen. They show that the sulfur was almost certainly an original constituent of the sediments and that the nature of both sulfur and oxygen isotopes indicates the ore bodies obtained their concentrations of sulfur and quartz from nearby sources during metamorphism. Much of the vein quartz of the ore bodies may be merely dissolved and reprecipitated cherty quartz from the Homestake Formation.

Other data cited by Rye and Rye are compatible with the theory of ore deposition from fluids migrating into zones of dilation during 
metamorphism. A key element in the process may, in their view, have been the alteration at the garnet isograd sideroplesite to cummingtonite, which would have released carbon dioxide to the fluid. They suggested that the metamorphism was the 1,700-million-year-old event of the Black Hills, as did Kulp and others (1956) as a result of a lead-lead age determination.

Trace amounts of metals, including gold, are widespread in iron-formations of the Black Hills, and the Rye and Rye results leave little doubt that the same processes affected them. Rye and Rye likened the depositional environment of the Homestake Formation to the hot brine deeps of the Red Sea.

Noble (1950, p. 247-248) was puzzled about why gold is localized in the Homestake Formation and is scarce or absent in chemically similar nearby rocks. He suggested only that some slight difference in the chemical properties of the Homestake rock made it more receptive to hydrothermal mineralization. The now probable reason is that the Homestake Formation had more gold at the beginning. One must keep in mind that Noble was constrained by the theories of his time, which was before the large body of information now available on syngenetic metals deposits and their subsequent history had been amassed. The Homestake deposit, with its structural complexities, was no place for the invention of drastic changes in theories of origin of hydrothermal deposits. Noble $(1950$, p. 245-248) had the prudence to classify both the question of age and the question of ore localization in the Homestake Formation as "unsolved problems."

Three separate ore controls for the Homestake deposit have now been identified: (1) the Homestake Formation itself, because at least part of the original sediment contained gold and because most of this gold remained in the formation during later events; (2) the cross folds; and (3) the zone of metamorphic change, in rocks just above the garnet isograd, where sideroplesite gives way to cummingtonite.

Any locality where these three controls appear likely to come together is an exploration target worthy of considerable attention. The cross folds may be less important in exploration than the other ore controls, for metalliferous fluids passing through any available channels may well have. found other dilated structures in which to drop their load in a concentrated form.

Interestingly enough, S. F. Emmons (in Irving,
1904, p. 78-79), after brief examination of the Homestake mine 75 years ago, concluded that the deposit is at the juncture of a N. $30^{\circ} \mathrm{W}$. line of "major crushing" and a N. $10^{\circ} \mathrm{W}$. line of "minor movement" (presumably what is now called crossfolding), that there were both Precambrian and Tertiary periods of mineralization, and that the metals were derived by leaching from rocks at lower levels by percolating waters. At that time the science of economic geology, of which Emmons was one of the founders, and the mining of the Homestake deposit were not far beyond infancy.

\section{OTHER DEPOSITS IN IRON-FORMATION}

Units of iron-formation in many parts of the Black Hills are pockmarked with prospect pits, most of which probably were dug because the early prospectors found gold in pan concentrates; but some pits may reflect their knowledge that ironformation on iron-stained rock was a good place to look for gold. Analyses for the Rochford area published by Bayley (1972a, pl. 2) confirm the presence of gold. Places where iron-formation is thickened by folding seem most favorable; these localities contain the mines having a record of production, the diggings of sufficient extent to have once been called mines even though their history may now be vague or untraceable, and the groups of prospect pits that apparently achieved no fruitful result. The principal localities are near Rochford and at various places near Keystone, especially in a belt of iron-formation that goes northnorthwest through the village (Norton, 1960).

Interest in the Rochford district, which has long been considerable, is likely to be enhanced by the analyses of Bayley (1972a) and by his geologic map of the area and descriptions of the rocks and the principal mines and prospects. Recorded gold production is only a few thousand ounces, and unrecorded production cannot increase the total beyond a very few tens of thousands of ounces. Part of the reason for the modest productivity may have been low mill recoveries.

The Rochford area has three units of quartzgrunerite schist that very closely resemble the Homestake Formation (Bayley, 1972a, p. 6). One of these units, which Bayley (1972a, p. 5-6) named the Rochford Formation, was in fact long regarded as Homestake Formation on the southerly plunging upside down nose of a syncline (Noble and Harder, 1948, p. 954-955; Harder, 1934). Bayley, however, found that the structure is anticlinal, that the supposed Homestake Formation is a part of the Flag 
Rock, which he raised to a group, and that the real Homestake Formation must be deeply buried, if indeed it exists in the area at all. Bayley's evidence is sufficiently persuasive to allow little room for the possibility that any iron-formation in this area is actually the Homestake Formation. Yet the lithologic nature and gold content of the rock point to a similarity in origin, as do the isotopic data of Rye and Rye (1974). The area may indeed contain sizable gold deposits in suitable structural and metamorphic environments, if not at Rochford then in places to the north beneath Paleozoic cover.

In the Keystone region most if not all the mineralization in iron-formation is Precambrian. At Keystone itself, however, a series of deposits from the Bullion mine to the Bismark mine is alined along a breccia zone containing slickensides of such fresh appearance as to indicate a very youthful age. The breccia may have formed after the mineralization, but the coincidence of the two suggests that the mineralization was, at least in part, a result of redistribution of metals in the Tertiary.

The most curious aspect of deposits in ironformation is that exploration for gold or other metals has been remarkably unrewarding except at Homestake. Perhaps these other iron-formations had less gold in the original sediment, but another explanation lies in the probability that one of the ore controls of the Homestake deposit is its position slightly above the garnet isograd. Nearly all the Black Hills Precambrian rocks are above the garnet isograd. The only known exception is west of Lead, though there may be others in the northeast part of the Precambrian area. The southern Black Hills is mostly above the staurolite and sillimanite isograds. Deposits may have formed in rocks of lower metamorphic grade once overlying the region, but if so they were eroded away later in the Precambrian, and the gold was carried to places now unknown and undeterminable but surely buried deeply beneath Paleozoic cover.

\section{GOLD QUARTZ VEINS}

Quartz veins having gold in the quartz or in the wallrock have been found in many places in Precambrian rocks, mostly in quartz-mica schist, but probably only because that is the most abundant kind of rock in the region. Vein quartz in iron-formation or in associated rocks is of course excluded here, as it belongs with the deposits described on preceding pages.

Workings range from the smallest of prospect pits to mines of moderate size, of which the Holy Terror and the Clover Leaf yielded the most gold. Most of the so-called mines, however, are more properly described as large exploration openings, for they never matured into productive and profitable operations. Of the 51 square miles of Precambrian rocks north of Custer in the Berne quadrangle, which is representative of the southern Black Hills and perhaps of the entire Black Hills, Redden (1968, p. 402) lists nine small gold quartz mines in mica schists $(9$ deposits in $51 \mathrm{sq} \mathrm{mi}$ is representative abundance).

Four mines had enough production to warrant particular mention; the host rock is quartz-mica schist at each of these localities. The Clover Leaf (formerly Uncle Sam) mine at Roubaix is a saddle reef in a minor anticline plunging $40^{\circ} \mathrm{SE}$; 便 thickness of quartz is about 10 feet $(3 \mathrm{~m})$ in one limb, 20 feet $(6 \mathrm{~m})$ in the other, and considerably greater in the crest (Irving, 1904, p. 92-93). Mining was from a vertical shaft 750 feet $(227 \mathrm{~m})$ deep (Allsman 1940, fig. 3). Ore can be expected to continue to greater depths (Bayley, 1970, p. 9), but excessive water, modest ore grade, and low mill recoveries seem to have been the causes for discontinuing the operation. The Holy Terror mine at Keystone, mined to a depth of 1,200 feet $(366 \mathrm{~m})$ (Allsman, 1940, p. 91), is on a quartz vein of steep dip and N. $35^{\circ} \mathrm{W}$. strike. The Empire mine, 5 miles $(8 \mathrm{~km})$ northwest of Keystone, is a combination of two older mines on two separate quartz veins, each of $\mathrm{N}$. $30^{\circ} \mathrm{W}$. strike and steep southwest dip, opened to a depth of 650 feet $(198 \mathrm{~m})$ (Allsman, 1940, p. 75-77). The J. R. mine, 3 miles (almost 5 $\mathrm{km}) \mathrm{N} .60^{\circ} \mathrm{E}$. of Hill City, is on a north-striking vein of moderate west dip in which the quartz and mineralized wall rock have a thickness of $3 \frac{1 / 2}{2}$ to 4 feet $(1 \mathrm{~m})$ (Allsman, 1940 , p. 80).

It is generally assumed, probably correctly, that most of the gold quartz veins formed in the Precambrian. Not only has no similar mineralization been recognized in younger rocks, but also the occasional particles of gold reputed to have been found at the base of the Deadwood on the southwest side of the Precambrian rocks seem likely to have come mostly from quartz veins, for these are virtually the only gold deposits nearby.

Nevertheless, a surprising feature of several of these deposits is that they are near breccia zones of remarkably fresh appearance, which is a rare feature in the Precambrian rocks. The movement along faults containing these breccias may well have been mainly in the Precambrian, but some youthful movement, perhaps accompanied by 
mineralization, seems indisputable. Ratté and Wayland (1969, p. 13) mentioned such breccia accompanied by gold along the Burnt Fork fault. They also (1969, pl. 1) mapped a zone of breccia and silicified rock, 1 mile long and as much as 550 feet wide (about 1,600 by $165 \mathrm{~m}$ ), that at its northeast end, according to my own findings, branches into two breccia zones. One branch is near one of the quartz veins and the other near the second of the quartz veins in the Empire mine. One of these breccia zones can be seen in what is known as the Climax adit. The very similar breccia zone at the Bullion mine, which has already been described, is parallel to another such zone in the Keystone mine 500 feet to the southwest, and only 500 feet farther southwest is the Holy Terror quartz vein.

Little is known about the geology of the Keystone mine except that a major Precambrian fault goes through or near the workings (Norton, 1960). A small area at the entry of the main adit, which was found to be open and was entered in 1970, contains a breccia zone of N. $48^{\circ} \mathrm{W}$. strike and $70^{\circ} \mathrm{NE}$. dip that is close to or exactly on the large fault. A map published by Allsman $(1940$, p. 95$)$ indicates that the mine workings are parallel to this breccia zone. Nevertheless, it remains unknown whether the gold is with vein quartz, is in mineralized breccia, or replaces narrow beds of iron-formation corresponding to those exposed about 1,500 feet $(460 \mathrm{~m})$ to the northwest.

\section{DEPOSITS IN BASAL CONGLOMERATE OF DEADWOOD FORMATION}

The only truly productive deposits at the base of the Deadwood Formation are at a few localities where Cambrian rocks cap hilltops on the west, north, and east sides of the original outcrop of the Homestake deposit. The best ore was mined in very early years (about 1876-81). For descriptions, one must depend chiefly on Irving (1904, p. 98-111, 181184), whose work followed the abandonment of most of the mines, and on Devereux (1882), whom Irving himself quoted at length. According to Irving (1904, p. 109-111), the gold takes three forms: (1) detrital gold, "Apparently***the most important source of value in the ores," of which he found many well-rounded examples, one of them a nugget "nearly one-half inch in diameter*** of undoubted detrital origin"; (2) gold subsequently dissolved and reprecipitated nearby, some of it in underlying schist; and (3) gold introduced with pyrite, presumably in Tertiary time. Pyrite, or more com- monly iron oxide derived from pyrite, is abundant in the matrix of the conglomerate virtually everywhere that gold is present and absent where gold is absent (Irving, 1904, p. 99, 107-108). This circumstance calls to mind the oxidized and pyritic phases of replacement deposits higher in the Deadwood and raises doubt that any of the gold is detrital-a deficiency not mentioned by Irving but which was repaired for him by Noble $(1950$, p. 246$)$. Noble had the workings reopened and in his subsequent examination found no obvious detrital gold.

Nevertheless, early observations made at the time of mining should not be casually passed over. Gold of apparently detrital origin surely was observed (Irving 1904, p. 109; Devereux, 1882, p. 468-469). Devereux (1882, p. 473) pointed out that the durability of the Homestake outcrop would enable it to form an island in the Deadwood sea around which gold-bearing conglomerate would accumulate. Irving (1904, p. 99-104) elaborated on this thesis with a description of the apparent preDeadwood topography and its relations to stratigraphic units within the Deadwood. Gold was most abundant in the deepest depressions and conglomerate is thickest in these depressions. Conglomeratic fragments, especially large fragments of schist, diminish in abundance away from the Homestake lode, indicating they were derived locally. Overlying quartzite and the still higher dolomites and shales lap onto the supposed island, and only the higher horizons are represented near the site of the Homestake outcrop.

The conglomerate is thick at other localities adjacent to inferred pre-Deadwood topographic highs (Kulik, 1965, especially pls. 2, 3, 6, 14), but evidence that they contain gold is sparse. Elsewhere the conglomerate is generally thin and unproductive or absent. A few mines that operated chiefly in replaced dolomite also contained gold in the underlying quartzite or conglomerate; Shapiro and Gries (1970, p. 30, 31, 124) and Irving (1904, p. 144) cited several examples but showed that nearly all such gold was of replacement rather than placer origin.

At Rockerville, in the east-central part of the Black Hills, the conglomerate is perhaps 20 feet or more (about $6 \mathrm{~m}$ ) thick. Old workings scattered along the Precambrian-Deadwood contact northeast and east of Rockerville are large enough to verify the presence of gold but too small to indicate that mining was of more than modest 
success. According to Perry Rahn (oral commun., 1972), surficial material overlying nearby Precambrian rocks has many pits in what appear to be relicts of the pre-Deadwood surface. These presumably contained placer gold that had worked its way into underlying weathered rock. Nevertheless, most of the Rockerville mining appears to have been in Quaternary gravels to the east.

\section{REPLACEMENT DEPOSITS IN DEADWOOD FORMATION}

Most of the gold from the Deadwood Formation has come from replacement bodies in dolomite just above the quartzite near the base of the formation and from dolomite high in the section, a few feet below the Scolithus sandstone. These are known as the "lower contact" and "upper contact" ores, though these terms have no reference to any geologic contact. ${ }^{2} \mathrm{~A}$ few replacement deposits have been mined in the basal quartzite.

Aside from the Maitland and Wasp No. 2 mines (table 1 ), virtually all the mined ore bodies are within a rectangle about 5 miles $(8 \mathrm{~km})$ long in a westward direction and 3 miles $(5 \mathrm{~km})$ wide, having Lead at its northeast corner. Much of this rectangle is occupied by Tertiary igneous rocks, Mississippian units, and Precambrian rocks, but a sizable share of it has outcrops of the Deadwood Formation. Most of the Deadwood production has come from two small areas: the Ruby Basin district, about $1 \frac{1}{2}$ square miles $\left(6 \mathrm{~km}^{2}\right)$ in extent, $2 \frac{1}{2}$ miles west-southwest of Lead; and the Portland district, about 1 square mile $\left(2 \frac{1}{2} \mathrm{~km}^{2}\right)$ in extent, centered near Trojan 3 miles (almost $5 \mathrm{~km}$ ) west of Lead.

The mining region has many hills and valleys which expose rocks from well below the Precambrian surface upward to the Pahasapa Limestone (Mississippian). The most abundant rocks belong to the Deadwood Formation or to Tertiary intrusions, which are common on the higher mountains and as sills within the Deadwood Formation. The topography has facilitated tracing the orebearing horizons of the Deadwood. Most of the discoveries were undoubtedly made by prospecting in this way.

\footnotetext{
${ }^{2}$ Shapiro and Gries (1970, p. 29) suggested that this odd usage originated in a mine that had ore at the lower and upper contacts of a thick sill; this is plausible, except that Shapiro and Gries based their statement on Crosby (1888), who said nothing to indicate that these terms were in use during his time. Even more illogical is use of the term "intermediate contact" for ore at intermediate levels. Moreover, the name "Bald Mountain," from one of the prominent peaks of the region, has been applied in three different ways to Deadwood mining areas: (1) to the whole of the Portland-Ruby Basin area; (2) to the Ruby Basin district alone; and (3) to the most important mining company in the area, which, adding further to the confusion, operated chiefly in the Portland district.
}

The replacement deposits are at the edge of a dome which encompasses the whole Deadwood-Trojan region and which has near its center a Tertiary stock of several square miles, known as the Cutting stock, which is 2 miles ( 3 $\mathrm{km}$ ) northwest of Lead. The principal deposits are along the south and northeast sides of the stock. Elsewhere in the vicinity of the stock, Deadwood outcrops are sparse or absent, and thus Deadwood gold deposits are necessarily absent also.

Ore occurs where vertical mineralized fractures or groups of fractures intersect beds of dolomite, which are replaced outward from the fractures. The first comprehensive description of the structure of these elongate ore bodies, or "shoots," was by Irving $(1904$, p. 124-136, pl. 11), who said that common dimensions are 100 to 800 feet ( 30 to $240 \mathrm{~m}$ ) in length, 5 to 100 feet $(1.5$ to $30 \mathrm{~m})$ in width, and 1 to 10 feet $(0.3$ to $3 \mathrm{~m})$ in thickness. According to Miller (1962, p. 31), maximum dimensions are somewhat more than 5,000 feet $(1,525 \mathrm{~m})$ in length, 100 feet $(30 \mathrm{~m})$ in width, and as much as 22 feet $(7 \mathrm{~m})$ in thickness. But greater lengths and widths are attained where closely spaced vertical fractures cause ore bodies to coalesce. Some ore bodies are also controlled by contacts with Tertiary intrusions (Shapiro and Gries, 1970 , p. 48), which undoubtedly increase the geometric complexity.

The geologic map by Irving (1904, pl. 9) and maps of mine workings compiled by Shapiro and Gries (1970, pls. 9-11) show that the dominant strike of the ore shoots is due north in the Ruby Basin district, where most of the ore is in the "lower contact" zone, and N. $45^{\circ}-55^{\circ}$ E. in the Portland district, where both the "upper contact" and the "lower contact" have been productive. Northwesterly and westerly trending ore shoots are also common. Less significant vertical fractures trend in many other directions and either widen the ore bodies or cause branching and anastomosing shapes.

The northerly and northeasterly trends of the larger ore bodies suggest control by radial fractures around the Cutting stock (Slaughter, 1968, p. 1444, fig. 1), but the results of more detailed fracture studies of Shapirc and Gries (1970, p. 45-48, pl. 8) indicate that this appearance is misleading. Fractures having northeast and northwest strikes are common throughout the region, so they probably are older than the Tertiary igneous rocks and are unrelated to any individual intrusion. The 
northerly trend in the Ruby Basin district seem to be associated with faults of the same strike, which are in part older and in part younger than the Tertiary intrusions. Irving (1904, p. 132-133) suggested a less simple scheme but showed clearly that some fractures and the ore accompanying them are older and some younger than the associated intrusions.

The Deadwood replacement ore in an unaltered state, as first comprehensively described by Irving (1904, p. 136-144), is a very fine grained siliceous pyritic rock; gold had been identified only in telluride form until Connolly (1927, p. 77-90) showed that most of the gold is included in pyrite. Much of the ore has undergone oxidation, which has destroyed the pyrite and made the gold more readily obtainable; this "red" or "brown" ore, as it was called, was the source of most of the gold mined before the late 1920's. Oxidation occurred along contacts between ore and adjacent dolomite and-along fractures and bedding planes (Irving, 1904, p. 140; Connolly, 1927, p. 93).

The ore has always been classed as refractory, though technical developments over the years have greatly increased recoveries. By ordinary cyanide procedures of the early years (Connolly and O'Harra, 1929, p. 164) the unaltered or "blue" ore yielded no more than one-third of the gold present. Even the oxidized ore was difficult to treat, for the gold is very finely divided and it required correspondingly fine grinding. Oxidation diminishes the refractory nature of the ore probably by shattering the quartz as well as breaking down the sulfides and tellurides (Connolly, 1927, p. 94). The depletion of oxidized ore and the necessity of depending on unaltered ore encouraged the use of roasting to break down the ore, and recovery ultimately attained about 85 percent (Connolly, 1927, p. 89-91; Leaver and Woolf, 1928, p. 23-52; Miller, 1962, p. 49; Allsman, 1940, p. 45). After World War II, cyanide techniques had improved so greatly that similar recoveries could be obtained from much of the "blue" ore without roasting (Miller, 1962, p. 48). Probably most of the "blue" ore has now been mined or is inaccessible (D. T. Delicate, oral commun., 1973). In the mining methods used in the region, pillars were robbed on retreat, and waste rock was commonly backfilled (Miller, 1962, p. 77-78, 82).

According to Miller (1962, p. 48) the grade of all ore mined by the Bald Mountain Mining Co. and its predecessors from 1912 to 1959 was 0.186 ounce of gold and 0.617 ounce of silver per ton, though data from Allsman (1940, p. 28) for the years 1901-
37 indicate that 0.237 ounce of gold and 0.354 ounce of silver were recovered per ton of ore. Corresponding figures for the Golden Reward mine between 1901 and 1922 are 0.388 ounce of gold and 0.767 ounce of silver, and for the Mogul they are 0.234 ounce of gold and 0.485 ounce of silver. At the prices of 1973 and early 1974, these yields would amount to about $\$ 20$ to $\$ 60$ per ton of ore. Under modern economic conditions, ore near the lower end of this range, especially in small and irregular ore bodies, may be as marginal as it was under the conditions when mining was most active, but the richer and larger ore bodies would clearly be attractive.

The Deadwood replacement ores have been universally regarded as Tertiary in age and as related to the Tertiary intrusions. The chief dispute has been whether the Homestake deposit is of similar age and origin, and this question has now been settled in the negative by Rye and Rye (1974), who show that the isotopic properties of the two kinds of ore are distinctly different. Their work on Tertiary deposits was more on the Tertiary minerals of the Homestake mine and on lead-silver ores of the Deadwood Formation and Pahasapa Limestone than on the gold deposits, thus perhaps leaving room for further investigation of the nature of gold mineralization in Paleozoic rocks. Nevertheless, their data indicate that Tertiary ore minerals were deposited by hydrothermal fluids associated with the igneous activity of that time, and that the sulfur and presumably the gold were obtained from Precambrian rocks. Though they say the proximity of the Tertiary and Precambrian deposits may not be a result of chance, the question remains open about whether the Deadwood replacement gold came from the so-called Homestake Formation or whether the two have a more remote relationship. Though the results are not as satisfying as clear proof, they do allow the Deadwood deposits to be regarded as a traditional geochemical anomaly in that they indicate exploration of underlying rocks is worthwhile.

\section{DEPOSITS IN PAHASAPA LIMESTONE}

Except for a few examples of mineralization noted in the Whitewood Limestone by Shapiro and Gries $(1970$, p. 50, 100, 196), none of the stratigraphic units between the Deadwood Formation and the Pahasapa Limestone are likely sources of gold. Deposits in the Pahasapa resemble those in the Deadwood except for their much smaller abundance and productivity. The principal deposits are 
east and northeast of Savoy, especially on the flanks of Ragged Top Mountain, which is formed from a Tertiary intrusion; the Carbonate district northeast of Ragged Top is mainly a lead-silver area. The Ragged Top ore bodies were formed by lateral replacement of limestone along northeaststriking vertical fractures. They are thus similar to deposits in the Deadwood Formation, but there is no obvious reason why one bed is selected for replacement in favor of another (Irving, 1904, p. 172-177). The replaced beds are highly silicified. Sulfides are virtually absent, but tellurium has been detected.

Most of the mining in the Ragged Top area was done after Irving's visit there, and Darton and Paige (1925, p. 29) added little to Irving's account. Evidently, no geologist has published observations made while the mines were in full operation.

The supposition that mineralized vertical fractures in the Pahasapa are a sign of ore at depth has long been a source of encouragement to deep exploration in the Ragged Top and Carbonate region. More concrete evidence of ore at depth lies in the existence of modest amounts of ore in Deadwood dolomite at the Cleopatra mine (Shapiro and Gries, 1970, p. 183-185), which is 2 miles (about 3 $\mathrm{km}$ ) north-northeast of Ragged Top and near the southwest edge of the Carbonate district. According to Allsman (1940, p. 52) exploration at Ragged Top through a 500 -foot $(150-\mathrm{m})$ shaft and a 500 -foot drill hole extended to the lower Deadwood, but, though ore was said to have been found, work was discontinued. Two nearby diamond drill holes to explore the Pahasapa and the Deadwood also had small results (Shapiro and Gries, 1970, p. 156-157).

\section{DEPOSITS IN TERTIARY IGNEOUS ROCKS}

The only significant deposits thus far found in igneous rocks are in and near the Gilt Edge and Hoodoo-Union Hill mines, northeast of Strawberry Ridge, 5 miles $(8 \mathrm{~km})$ east-southeast of Lead. Small amounts of ore, part of it very rich, have been found elsewhere: some at Mineral Hill, just across the state line in Wyoming (Darton, 1905, p. 11); some northwest of Lead (Allsman, 1940 , p. 56$)$; some on Squaw Creek, 4 miles $(6 \mathrm{~km})$ or less northeast of Savoy (Irving, 1904, p. 97); and some, of course, in rhyolite in the Homestake mine itself. Adjacent Paleozoic or Precambrian rocks are also commonly mineralized.

According to Irving $(1904$, p. 97$)$, the ore at and near the Gilt Edge mine, which he visited in
1899 prior to the principal period of mining (1900-1908), is in limonitic fracture fillings and adjacent weathered porphyry near the surface and in pyritic rock downward from the surface. Allsman (1940, p. 57) confirmed this but added that at the intersection of fractures most of the ore bodies are in breccia.

\section{QUATERNARY AND TERTIARY PLACER DEPOSITS}

In the earliest gold-rush years, placer deposits were the scene of nearly all mining; the Deadwood Gulch area was by far the most productive. It soon became obvious, however, that placer mining was going to be only a minor activity. Nevertheless, placer operations, generally on only a small scale, continued sporadically through later years and intensified during the 1930's. Even today some gold is taken from placer deposits, but more as recreation for amateurs than as profitable enterprise. Attempted dredging operations and use of other mechanical equipment have been marked more by optimism than success.

Most of the placer mining was at or near valley bottoms, where water was readily available. Streams that drain a large area of Precambrian rocks have been most favored (Connolly, 1933, p. 14). One important exception is Rockerville Gulch, which drains only about 3 square miles of Precambrian rocks and which obtained most of its gold from basal conglomerate of the Deadwood Formation. Because Rockerville Gulch contained insufficient water, a $17-$ mile $(27-\mathrm{km})$ flume was built to bring water to this deposit.

Gold in attractive amounts has been found in many terrace gravels on the walls of present-day stream valleys, but these deposits tend to be small and sparsely distributed, and easily available water is lacking. Other gravels have little readily apparent relationship to the modern drainage systems. High-level gravels may have received less attention than they deserve.

Oligocene sands and gravels, mapped by Darton and Paige (1925), occur even at rather high altitudes and indicate that much of the Black Hills became covered at Oligocene time. Whether gold that eroded from older rocks was concentrated anywhere in these sediments or whether virtually all of it was dissipated is unknown. The Homestake lode cannot have been a contributor to such deposits, for it was only slightly eroded between Cambrian and modern times, and whatever placer gold it did yield went, with gold from the nearby Cambrian deposits, into the gravels mined in the Deadwood Gulch area. Thus, the most obvious 
sizable source for gold in Oligocene sediments is the many square miles of Deadwood Formation eroded from the northern Black Hills. A site in the southern Black Hills that has attracted some attention is the Pleasant valley, 9 miles $(14 \mathrm{~km})$ southwest of Custer, where about 200 acres of Oligocene sediments was mapped by Redden (1963, p. 274, pl. 21). Perhaps an effort to decipher the Oligocene drainage pattern of the Black Hills region would lead to the discovery of gold concentrations, but the investigation would be difficult and probably fruitless.

\section{PROPOSED APPROACH TO EXPLORATION}

The known facts about the distribution of ore indicate that exploration for new major gold deposits should be chiefly in the northern Black Hills. Production figures indicate that the primary objective should be to find a new deposit of the Homestake type, but discovery of a new area of Deadwood deposits might be worthwhile.

The large amount of prospecting in the past virtually eliminates hope that sizable deposits of any kind can now be found at the surface. All discoveries to date have been made either at the outcrop or through exploration within existing mines. No truly new deposit has been found in the Black Hills since shortly after the gold-rush years. Yet unmistakable evidence shows that concealed deposits may exist in unexplored localities.

The long-standing belief by Noble and his associates that the Homestake deposit is of Tertiary age must have led them, as it did me some years ago, to the conclusion that deposits in the Deadwood and younger rocks are a sure sign of ore in nearby Precambrian rocks. Yet exploration directed by them based on this thesis seems to have been meager, probably because gold mining, even at Homestake, was marginal for a long time.

Furthermore, few efforts have been made by others to find concealed deposits, even though the appeal of making the attempt was noticed long ago. Of the many drill holes through the Deadwood Formation, few have penetrated more than 20 feet $(6$ $\mathrm{m}$ ) into Precambrian rocks (Shapiro and Gries, 1970, p. 215-222). A considerable effort was made at the Maitland mine between 1912 and 1915 to find ore by searching for underlying Homestake Formation (Shapiro and Gries, 1970, p. 124). In retrospect, one recognizes that the failure of any of the vertical fractures in Deadwood deposits to lead to underlying ore was a very discouraging sign. This failure was also evidence that the Deadwood replacement deposits and the Homestake deposit are of different age and that the presence of one does not require the nearby presence of the other.

The Deadwood conglomerate ores can be viewed differently. Whether the Homestake deposit is Tertiary or Precambrian and whether the gold in the conglomerate is introduced or is fossil placer, gold in any conglomerate would seem to indicate that gold is close at hand in Precambrian rocks, and in fact the two did occur together at the outcrop of the Homestake lode. The view that the conglomerate should be thoroughly investigated has long appealed to me but apparently has had no other proponents, probably because it seemed more practical and useful to obtain other kinds of geologic information beforehand.

The assurance now that mineralization was of both Precambrian and Tertiary age adds complications to the exploration problems, but at the same time it explains the absence of simple relationships and the lack of discoveries of Precambrian deposits directly beneath deposits of Tertiary age. The distribution of Tertiary ore is still useful information, for its gold did come originally from Precambrian sources, whether close by or far away.

The problem now arising is how to use the younger rocks as guides to the locations of Precambrian deposits. A buried deposit that once was exposed on the pre-Deadwood surface offers the least difficulty, or so it would seem in theory, for one should be able to find its approximate location by determining the distribution in basal Deadwood rocks of gold and other metals useful as geochemical tracers and, by ascertaining enougi about the pre-Deadwood topography, to guess the positions of hills of quartzose mineralized rock and channels that might have brought gold from a mother lode. Any deposit whose top is below the pre-Deadwood surface will be very hard to find. Helpful hints can be obtained by determining the distribution of introduced gold and other metals in the Deadwood and by learning where the so-called Homestake Formation or similar iron-formations are likely to be found in a suitable metamorphic and structural environment. An unavoidable conclusion is that quick and cheap methods of exploration will not suffice unless, of course, exceptional good luck prevails. A comprehensive and costly investigation should be regarded as necessary.

The program I favor would require a new and detailed geologic investigation of an approximately 120 -square-mile $\left(300-\mathrm{km}^{2}\right)$ area roughly bounded by Spearfish Peak on the north, Savoy on the west, 
Cheyenne Crossing on the south, and the Galena lead-silver district on the east. A geologic map of this area that would be satisfactory in most respects can be compiled at the $1: 24,000$ scale of available topographic maps from existing information, but full field study to increase the detail would be required. Paleozoic rocks and some of the younger rocks in much of the area have recently been mapped by Shapiro and Gries (1970, pls. 2-6). Maps by Bayley (1972c) and by Noble, Harder, and Slaughter (1949, pl. 1) show the main Precambrian features. Mukherjee (1968, pl. 1) mapped about 10 square miles near Galena. The entire area is covered by a map at a scale of $1: 62,500$ by Darton and Paige (1925). These maps are not in all respects reconcilable with one another.

Geologic mapping of perhaps 40 square miles $\left(100 \mathrm{~km}^{2}\right)$ straddling the South Dakota-Wyoming State line at Tinton, or at last a thorough examination of this area, would be worthwhile. Reputedly rich placers worked in early years have no obvious source for their gold; this peculiarity calls for a search for the explanation.

The physical stratigraphy, structure, and geochemistry of the Deadwood Formation should receive close attention. Unfortunately, outcrops of the Deadwood are sparse in many places, both because of its own weathering characteristics and because cliffs of Pahasapa Limestone shed rubble over older rocks. A truly detailed study is likely to require short core-drill holes, which perhaps can be made from a truck-mounted rig. The Deadwood Formation should also be examined for about 30 miles ( 48 $\mathrm{km}$ ) southward, to Rockerville on the east and Bear Mountain on the west, to supplement the stratigraphic work of Kulik (1965) and to test by geochemical sampling the possibility that gold deposits are concealed nearby.

A reexamination of the petrology and structure of the Tertiary igneous rocks is desirable and perhaps essential. The absence of any comprehensive report on them since the time of Darton and Paige (1925, p. 16-17, 19-24) seems a serious shortcoming, for the repeated references to a connection between Tertiary mineralization and igneous activity leave little doubt of the need for a fuller understanding of this subject.

Precambrian rocks, though also occupying a sizable share of the area, have been so closely mapped in the past (Noble and others, 1949, pl. 1; Bayley, 1972c) that they should cause few problems, though the rocks west and northwest of the Lead area should be mapped in more detail than heretofore.

Organizations in a hurry, and with the funds to indulge their impatience, might be justified in starting deep-hole diamond drilling in the most obviously favorable areas at an early date. Plans for such a program should allow for many thousands of feet of drilling over an area of several square miles to test the structure, stratigraphy, and metals contents in both Cambrian and Precambrian rocks. A vertical hole collared near the top of the Deadwood Formation could require 400 to perhaps 900 feet $(120$ to $270 \mathrm{~m})$ to reach the Precambrian contact, depending on the thickness of Tertiary sills encountered (Shapiro and Gries, 1970, p. 58). Inclined holes might be more informative in many places, for they will cut across vertical veins in the Deadwood Formation and will also yield a cross section of the Precambrian rocks, which generally have a steep dip.

One may ask why no program of the kind advocated here has ever been attempted, even though the need for it has been recognized. The most obvious reason is that the price of gold became attractive only recently. Other reasons lie in shortcomings in knowledge of Black Hills geology, several of which have been eliminated in the last few years. The question of the age of Homestake mineralization now seems to have been settled by Rye iand Rye (1974); the need for geologic mapping of Precambrian rocks south of the Lead region has been eliminated by Bayley $(1970,1972 a, b, c)$; and the absence of any comprehensive study of the ore bodies in Deadwood and younger rocks since the time of Irving has been eliminated by the work of Shapiro and Gries (1970). All these recent reports, however, while helpful in planning the kind of work here proposed, have enhanced rather than diminished the obviousness of the need for further investigation.

\section{EXPLORATION TARGET AREAS}

Existing data suggest that three areas are suitable for exploration. A possible fourth, the area from Deadwood southeast to the Gilt Edge mine and the Galena lead-silver district, will not be discussed here because little can be said beyond the obvious statement that ore has been found at the surface.

\section{AREA NORTH OF LEAD}

The so-called Homestake Formation on both limbs of the anticlinorium at Lead disappears to the north beneath the Deadwood Formation or is 
cut off against Tertiary intrusions; it is not known with certainty that it reappears at the Precambrian-Cambrian boundary anywhere in the Black Hills.

On the west limb of the Lead anticlinorium, the Homestake Formation trends toward the Maitland mine and goes through a series of tight folds (Bayley, 1972c). The garnet isograd is headed in this same direction (Noble and Harder, 1948, pl. 1). That this locality is an obvious place to search for ore of the Homestake type led to the previously mentioned unsuccessful exploration in the Maitland mine.

Deadwood outcrop trends in a generally northwesterly direction from Maitland (Darton and Paige, 1925, geologic maps). Immediately to the northeast it is covered by the thin Whitewood and Englewood Formations, followed by a broad blanket of Pahasapa Limestone. A few square miles of Oligocene sediments as well as Tertiary intrusive rocks also occupy the area. Surface indications of underlying ore would obviously be negligible or nonexistent. Yet the likely presence in the Precambrian rocks of the Homestake Formation, the presence of tight folds and the garnet isograd, and the existence of Deadwood ore in the Maitland mine all indicate that this area is an exploration target worthy of intensive investigation.

\section{PORTLAND AND RUBY BASIN REGION}

The Portland and Ruby Basin districts in the Trojan area contain the historically most productive Deadwood ore bodies, and that count alone justifies curiosity about what lies in underlying Precambrian rocks. The Deadwood Formation predominates at the surface for many miles to the south and southeast (Darton and Paige, 1925, geologic maps), where it undoubtedly has been thoroughly prospected with little or no success. Thus it appears that, until more encouraging evidence is discovered, areas of exposed Deadwood rocks far removed from old mines are not of immediate interest. Pahasapa Limestone occupies the higher hills, and Tertiary intrusions are common.

Still farther south, the Precambrian is exposed in an anticlinorium in which the oldest rock is probably equivalent to Noble and Harder's Ellison Formation (Bayley, 1972a, p. 3, pl. 1). The strike of this anticlinorium would carry it beneath the Portland and Ruby Basin districts. Just north of these districts, Noble and Harder's Ellison reappears (Bayley, 1972c) in a manner that implies that the anticlinorium continues beneath this en- tire region of Paleozoic cover. Whether the Homestake Formation exists at all in this region and whether, if it does exist, it is ever at the Precambrian-Cambrian contact is unknown. If it is at or not far below this contact, the Portland and Ruby Basin region is as good a place as any to look for it.

The literature does not record what happens to the garnet isograd south of where it was mapped at Lead (Noble and Harder, 1948, pl. 1). Rocks in the Rochford region, however, are above the garnet isograd, and so also are most or all of the Precambrian rocks along the east side of the Paleozoic rocks between Rochford and the Portland and Ruby Basin districts. One must, therefore, conclude that the garnet isograd extends from Lead southwest and perhaps west somewhere not far from Portland and Ruby Basin.

In short, this target area possesses Deadwood ore bodies, it may have so-called Homestake Formation beneath it, it may be near the garnet isograd, and it almost certainly has a tightly folded Precambrian anticlinorium. These facts, taken as a group, imply that exploration for a concealed Precambrian deposit may be rewarding.

\section{ROCKERVILLE AREA}

Deadwood conglomerate east of Rockerville has gold of apparently placer origin, and Quaternary placers to the east have been extensively worked. No one, however, seems ever to have been curious about where the gold came from originally.

The interpretation by Kulik (1965, p. 138-139, pl. 14) of the paleogeography at the start of Deadwood sedimentation attributes conglomerates mainly to wave action near islands and steep headlands. Kulik seems unaware of the conglomerate at Rockerville, but this is a small oversight in view of the breadth of area he studied.

One could suppose that the gold was washed in from Keystone, 6 miles $(10 \mathrm{~km})$ to the southwest. Another possible source area is Silver Mountain, 3 miles $(5 \mathrm{~km})$ to the west, where an island must have existed, but the rock there is mostly amphibolite, and such iron-formation as is present has prospect workings suggestive of only sparse gold. All in all, the exposed gold-bearing rocks west of Rockerville are unprepossessing as mother lodes for the gold in the Deadwood Formation.

Northwest of Rockerville is a unit called Ellison Formation on Bayley's open-file map (1972c) and by another name on his Nemo map (1972b). A body of iron-formation near the unit's northeast side is 
tentatively correlated with the so-called Homestake Formation (Bayley, 1972c), but it lenses out 13 miles $(21 \mathrm{~km})$ northwest of Rockerville. The supposed Ellison shows few folds in the Nemo region, but it becomes intricately folded to the southeast before it passes beneath Paleozoic cover (Bayley, 1972b, c). Folding of Precambrian rocks is also complex near Rockerville; 1.3 miles $(2.1 \mathrm{~km})$ to the southwest on U.S. Highway 16, J. A. Redden and I have seen three sets of folds of different shape and attitude in a single outcrop over a width of about 10 feet $(3 \mathrm{~m})$.

The strike of the presumed Ellison of Bayley should bring it within 1 mile $(1.6 \mathrm{~km})$ of the exposed conglomerate. Possibly, gold-bearing ironformation is also nearby, for hematite pebbles in Deadwood conglomerate have been observed in the Stratobowl just north of Rockerville (Kulik, 1965, p. 21). Furthermore, the sparsity and size of garnet near Rockerville suggest that the garnet isograd may not be far away. An investigation to evaluate the possibility that a concealed mother lode of Precambrian gold lies to the east is clearly justified.

\section{REFERENCES CITED}

Allsman, P. T., 1940, Reconnaissance of gold-mining districts in the Black Hills, S. Dak.: U.S. Bur. Mines Bull. 427, 146 p.

Anna, L. O., 1973, Geology of the Kirk Mill area, Lawrence and Meade Counties, South Dakota: South Dakota School Mines and Technology, unpub. M.S. thesis.

Bayley, R. W., 1970, Structure and mineralization of Precambrian rocks in the Galena-Roubaix district, Black Hills, South Dakota: U.S. Geol. Survey Bull. 1312-E, 15 p.

1972a, A preliminary report on the geology and gold deposits of the Rochford district, Black Hills, South Dakota: U.S. Geol. Survey Bull. 1332-A, 24 p.

$1972 \mathrm{~b}$, Preliminary geologic map of the Nemo district, Black Hills, South Dakota: U.S. Geol. Survey Misc. Geol. Inv. Map I-712.

1972c, Geologic field compilation map of the northern Black Hills, South Dakota: U.S. Geol. Survey open-file rept.

Berg, J. R., 1946, Precambrian geology of the Galena-Roubaix district, Black Hills, South Dakota: South Dakota Geol. Survey Rept. Inv. 52, 50 p.

Bergendahl, M. H., 1964, Metallic mineral resources-gold and silver, in Mineral and water resources of South Dakota: U.S. 88th Cong., $2 \mathrm{~d}$ sess., Senate Comm. Interior and Insular Affairs, Comm. Print [South Dakota Geol. Survey Bull 16], p. 41-49.

Connolly, J. P., 1927, The Tertiary mineralization of the northern Black Hills: South Dakota School Mines and Technology Bull. 15, 130 p.

1933, Geologic history of Black Hills gold placers: South Dakota Geol. Survey Rept. Inv. 16, 16 p.

Connolly, J. P., and O'Harra, C. C., 1929, The mineral wealth of the Black Hills: South Dakota School Mines and Technology Bull. 16, 418 p.
Crosby, W. O., 1888, Geology of the Black Hills of Dakota: Boston Soc. Nat. History Proc., v. 23, p. 488-517.

Darton, N. H., 1905, Description of the Sundance quadrangle [Wyo.-S. Dak.]: U.S. Geol. Survey Geol. Atlas, Folio 127.

Darton, N. H., and Paige, Sidney, 1925, Description of the central Black Hills [S. Dak.]: U.S. Geol. Survey Geol. Atlas, Folio 219.

Devereux, W. B., 1882, The occurrence of gold in the Potsdam Formation, Black Hills, Dakota: Am. Inst. Mining Engineers Trans., v. 10, p. 465-475.

Harder, J. O., 1934, Geology of a Precambrian area at Rochford and its relation to the regional structure of the northern Black Hills: South Dakota School Mines and Technology unpub. Engineer Mines thesis, 51 p.

Irving, J. D., 1904, Economic resources of the northern Black Hills, with contributions by S. F. Emmons and T. A. Jaggar, Jr.: U.S. Geol. Survey Prof. Paper 26, 222 p.

Kleinkopf, M. D., and Redden, J. A., 1974, Bouguer gravity, aeromagnetic, and generalized geologic map of the Black Hills of South Dakota and Wyoming: U.S. Geol. Survey Geophys. Inv. Map GP-903 (in press).

Kulik, J. W., 1965, Stratigraphy of the Deadwood Formation, Black Hills, South Dakota and Wyoming: South Dakota School Mines and Technology unpub. M.S. thesis, $263 \mathrm{p}$.

Kulp, J. L., Ecklemann, W. R., Gast, P. W., and Miller, D. S., 1956, Age of the Black Hills gold mineralization: Geol. Soc. America Bull., v. 67, p. 1557-1558.

Leaver, E. S., and Woolf, J. A., 1928, Cyanide extraction of gold and silver associated with arsenic and antimony in ores, with especial reference to those in Nevada and South Dakota: U.S. Bur. Mines Tech. Paper 423, 52 p.

Lochman-Balk, Christina, 1972, Cambrian system, in Geologic atlas of the Rocky Mountain region: Rocky Mtn. Assoc. Geologists, Denver, Colo., p. 60-75.

Miller, P. A., 1962, A study of the Bald Mountain mining area, Lawrence County, South Dakota: South Dakota School Mines and Technology unpub. Engineer Mines thesis, 124 p.

Mukherjee, N. S., 1968, Geology and mineral deposits of the Galena-Gilt Edge area, northern Black Hills, South Dakota: Colorado School of Mines unpub. Ph. D. thesis, 288 p.

Noble, J. A., 1948, High-potash dikes in the Homestake mine, Lead, South Dakota: Geol. Soc. America Bull., v. 59, p. 927-939.

1950, Ore mineralization in the Homestake gold mine, Lead, South Dakota: Geol. Soc. America Bull., v. 61, p. 221-251.

Noble, J. A., and Harder, J. O., 1948, Stratigraphy and metamorphism in a part of the northern Black Hills and the Homestake mine, Lead, South Dakota: Geol. Soc. America Bull., v. 59, p. 941-975.

Noble, J. A., Harder, J. O., and Slaughter, A. L., 1949, Structure of' a part of the northern Black Hills and the Homestake mine, Lead, South Dakota: Geol. Soc. America Bull., v. 60, p. 321-352.

Norton, J. J., 1960, Geologic maps of Hugo pegmatite and part of the Keystone district, Pennington County, South Dakota: U.S. Geol. Survey open-file rept.

Parker, Watson, 1966, Gold in the Black Hills: Norman, Okla., Univ. of Oklahoma Press, $259 \mathrm{p}$.

Ratté, J. C., and Wayland, R. G., 1969, Geology of the Hill City 
quadrangle, Pennington County, South Dakota-A preliminary report: U.S. Geol. Survey Bull. 1271-B, 14 p.

Ratté, J. C., and Zartman, R. E., 1970, Bear Mountain gneiss dome, Black Hills, South Dakota-age and structure: Geol. Soc. America Abs. with Programs, v. 2, no. 5, p. 345.

Redden, J. A., 1963, Geology and pegmatites of the Fourmile quadrangle, Black Hills, South Dakota: U.S. Geol. Survey Prof. Paper 297-D, p. 199-291.

1968, Geology of the Berne quadrangle, Black Hills, South Dakota: U.S. Geol. Survey Prof. Paper 297-F, p. 343408.

Riley, G. H., 1970, Isotopic discrepancies in zoned pegmatites, Black Hills, South Dakota: Geochim. et Cosmochim. Acta, v. 34 , p. $713-725$.

Rye, D. M., and Rye, R. O., 1974, Homestake gold mine, South Dakota: I. Stable isotope studies: Econ. Geology, v. 69, p. 293-317.

Shapiro, L. H., and Gries, J. P., 1970, Ore deposits in rocks of Paleozoic and Tertiary age of the northern Black Hills, South Dakota: U.S. Geol. Survey open-file rept., 235 p.
Slaughter, A. L., 1968, The Homestake mine, in Ridge, J. D., ed., Ore deposits of the United States, 1933-1967 (GratonSales volume), v. 2: Am. Inst. Mining, Metall., and Petroleum Engineers, p. 1436-1459.

Steece, F. V., 1964, Geology-Precambrian rocks of eastern South Dakota, in Mineral and water resources of South Dakota: U.S. 88th Cong., 2d sess., Senate Comm. Interior and Insular Affairs, Comm. Print [South Dakota Geol. Survey Bull. 16], p. 28-33.

U.S. Bureau of Mines, 1954, Black Hills mineral atlas; Part 1: U.S. Bur. Mines Inf. Circ. 7688, 123 p.

1955, Black Hills mineral atlas; Part 2: U.S. Bur. Mines Inf. Circ. 7707, 208 p.

Wayland, R. G., 1936, Cummingtonite from the Black Hills, South Dakota: Am. Mineralogist, v. 21, p. 607-610.

Zartman, R. E., and Stern, T. W., 1967, Isotopic age and geologic relationships of the Little Elk Granite, northern Black Hills, South Dakota, in Geological Survey research 1967: U.S. Geol. Survey Prof. Paper 575-D, p. D157-D163.

' U.S. GOVERNMENT PRINTING OFFICE: 1974-543-586/184 